\title{
The Important Role of Migration for an Ageing Nation
}

\author{
Sarah Harper ${ }^{1}$
}

Published online: 4 August 2016

(C) Springer Science+Business Media Dordrecht 2016

The British Referendum of June 23rd 2016 is set to be a defining moment in British history. Whether to be reconsidered or not, whether to result in a stronger or diminished UK and EU, analysts pouring over the voting data have identified key trends in the UK around generation, locality, income and education. But in particular there appears a complete public misunderstanding of the net contribution made by migrants to the UK.

As Fukyama's $(1992,2014)$ insightful analysis has long pointed out the transition from place based industrial work to mobile service work would threaten democratic regimes. The educated population required to capitalise on technological advances, would use their education to question current systems of governance. In addition, lower transportation and communications costs would enable hundreds of millions of low skilled workers to enter the global labour market, driving down the wages and potential living standards of those workers in developed countries. While the place based working class might be organised as a political force, in particular through workers organisation such as trade unions, the mobile workforce - increasingly in the informal sector - were hard to politicise. In addition is the destruction of local community. In a capitalist globalised world, traditional communities based on locality are threatened by the growing numbers of educated mobile people who live in communities where they did not grow up or where their families lived before them.

This thesis is clear to see here in UK 2016. A country in transition still retaining large numbers of place based individuals in towns and rural areas - generally less well educated and travelled due to the constraints of age and socio-economic background. With a growing section of the English population who had acquired the skills and education to live and compete economically in the more affluent southern parts of the country. ${ }^{1}$ These highly educated, overseas travelled UK citizens were more likely to vote to remain, those without further education, and not holding a passport, were more likely to vote to leave. Most strikingly, the 2016 UK post-referendum data found that of

${ }^{1}$ The small populations of Scotland and mid-west Wales also voted to remain.

Sarah Harper

sarah.harper@ageing.ox.ac.uk

1 Oxford Institute of Population Ageing, University of Oxford, Oxford, UK 
the 30 areas with the lowest number of graduates, 28 voted to leave. However, those communities experiencing high levels of immigration voted to remain, while communities with low levels of migrants generally voted to leave. While the evidence supports this - new EU migrants do displace earlier EU migrants in the UK labour market, but are not associated with the displacement of UK born workers (Migration Advisory Committee 2012) - the perception was different - reflecting not competition for jobs but competition for the cultural values of traditional England.

\section{Age-Structural Change}

It is not just technology and globalisation, however, which has encouraged the advanced economies to attract and facilitate the immigration of skilled overseas workers. It is also the age-structural change which is forcing governments to consider migration as a solution to the demographic deficit and population decline. As I have published elsewhere (Harper 2012, 2013) ${ }^{2}$ international research has consistently produced evidence to show the importance of migration for ageing countries. Migration has a potentially strong and long-lasting impact on population growth and structure through the interaction between the number of migrants, their relatively young age structure and their higher fertility. As a result, immigration has increasingly become perceived as a potential means to prevent population decline, maintain the size of the labour force and thus the support ratio, and slow down structural population ageing. Research shows that that the net contribution of migrants is nearly always positive, important given that the major challenge facing the ageing high income counties is one of growing skills shortages.

In terms of population size, while migration will not prevent the age-structural transition and demographic deficit of Europe it will alleviate it (Coleman 2002, Espenshade et al. 1982, Espenshade 2001, Feld 2000, Lesthaeghe 2000, Pollard 1973, Saczuk 2003). Indeed even with significant immigration, on average 800,000 per year, the population size in the EU is likely to be about the same level in 2050 as it is today. However, with no migration there would be immediate moderate decline followed by a steep decline after 2030, reaching 451 million by 2025, and 413 million by 2050, a fall of 40 million across the EU (Lutz and Scherbov 2007) .

\section{The Facts}

Recent analysis of census material (CPC 2016) presents the facts around the migrant population:

- The majority of the population of England and Wales (more than $86 \%$ ) were born in the UK. A small minority (4.3\% of men and about $4.7 \%$ of women) were born

\footnotetext{
${ }^{2}$ This editorial draws on two previously published papers: Harper, S. (2012). Environment, migration and the European demographic deficit. Environmental Research Letters, 7(1). Harper, S. (2013) PopulationEnvironment Interactions: European Migration, Population Composition and Climate Change. Environmental and Resource Economics, 55(4), 525-541.
} 
in other EU countries, some 2,509,900 individuals born elsewhere in the EU who were living in England \& Wales in 2011.

- Of these, $24 \%$ were born in Poland; $22 \%$ were born in countries which joined the EU between April 2001 to March 2011. $16 \%$ were born in Ireland, $11 \%$ in Germany and $27 \%$ were born in other countries of the pre-2001 EU.

- Of the EU-born UK population, $69 \%$ were aged between 20 and 60; compared with $51 \%$ of those born in the UK. Just $13 \%$ of the EU-born population were aged under 20 and $18 \%$ were over 60 , compared with $26 \%$ and $23 \%$ respectively of those born in the UK.

- $64 \%$ of EU-born UK migrants over 18 were employed compared with $58 \%$ of those born in the UK. A further $6 \%$ were students and only $16 \%$ were retired, compared to $3 \%$ and $24 \%$ respectively amongst the UK-born population, in part reflecting the younger age structure amongst EU migrants.

- $31 \%$ of EU-born UK migrants aged 18 and over living in England \& Wales in 2011 had a degree or higher academic or professional qualifications and only $18 \%$ had no qualification; this compares with $27 \%$ and $24 \%$ respectively amongst UK-born adults.

\section{Increase Workers}

The European share of global working age population has fallen from around $25 \%$ in 1950 to $14 \%$ in 1995 , and is projected to fall to $9 \%$ in 2025 and $6 \%$ by 2050 . These projections assume a natural fall in the net flow of migrants to Europe as a whole. This was based on the assumption that the proportion of global migrants to North America and Developed Oceania increases from $50 \%$ to $80 \%$ by 2025 , to the detriment of European flows. It is projected that if migration rates stay largely at their current levels, the working-age population in OECD countries will rise by $1.9 \%$ between 2010 and 2020 , compared to the $8.6 \%$ growth seen between 2000 and 2010 (IOM 2010). The IOM reports further predicts that while the incoming (20-24) working-age cohorts in OECD countries were some $32 \%$ larger on average than the outgoing retiring (60-64) ones in 2005, the situation in 2015 will be substantially different, with the incoming labour force cohorts being scarcely $2 \%$ larger. By 2020 they will be some $9 \%$ smaller. For almost half of OECD countries, the outgoing cohorts will be larger than the incoming ones in 2015. Indeed some projections indicate that without mass immigration into the EU of around 100 million there will be a need for a significant increase in labour force participation rates for all EU countries and a rise in retirement ages of 10 years by 2050 to compensate for the impact of demographic ageing on the work force (Prskawetz et al. 2006).

\section{Skills}

The impact on innovation, economic growth, employment in general, and welfare is more complex. Migrant workers fill both the demand for highly skilled workers and the gap in unskilled employment. Indeed the role of migrants as carers in this care sector is becoming increasingly important (Leeson 2010), nearly half the workers in the NHS for 
example, are oversees born. It is thus essential that Europe continues to attract key skills over the coming decades, and thus encourages enterprises who will attract such workers. Yet future projections also suggest that Europe's ability to attract skilled migrants will decline as it competes with North America, Oceania and Asia. As recently reported while countries of the EU are the world's leading destination for international students they have been unable to capitalise on this to build a solid bridge to labour migration for the graduates who are most needed (OECD 2016).

\section{Finance}

Migration also has an impact on the sustainability gap of public finances. Firstly, the net tax contributions of migrants directly affect the governmental budget balance; if the net contribution of migrants is positive, the sustainability gap declines. Secondly, immigration increases the number of potential tax payers, on whom future tax increases can be levied. For example, an active migration policy favouring highskilled immigrants may considerably enlarge the positive impact of immigration on the tax burden of native residents and decrease the fiscal burden of future resident generations (Bonin et al. 2000).

\section{Welfare}

A key question is whether immigrants are more or less likely than natives to use the provision of the welfare state (Barrett and McCarthy 2007; Borjas and Hilton 1996, Brücker et al. 2002) and/or whether immigrants assimilate into or out of the welfare state (Borjas and Trejo 1991, Hansen and Lofstrom 2003). Generational accounting assesses the intertemporal sustainability of public finances by calculating both the expected taxes and expenditures of public finances, based on long-term projections of the underlying fiscal and demographic variables. Of particular importance is whether migrants return to their birth country. The ageing of the migrant will then have future implications for public spending on old age welfare. However Rendall and Ball (2004) study of the UK suggests that almost half of overseas-born immigrants to the UK emigrate again within five years. This process of return migration among UK's overseas-born immigrants will thus lower the UK's old-age dependency ratio in at least the immediate future as they will not age in the UK.

Specifically a study of the UK (Dustmann et al. 2010), assessing the fiscal consequences of migration to the UK from the Central and Eastern European countries that joined the European Union in May 2004 (A8 countries) showed that those migrants with a least one year of residence, and thus legally entitled to benefits, are $59 \%$ less likely than natives to receive state benefits or tax credits and $57 \%$ less likely to live in social housing. They also concluded that A8 immigrants made a positive contribution to the public finances despite the fact that the UK has been running a budget deficit over the last few years. This is because they have a higher labour force participation rate, pay proportionately more in indirect taxes and make much less use of benefits and public services. The conclusion that overall migrants make a net contribution in the UK is reached in several other studies: Home Office (Gott and Johnson 2002) ; IPPR (Sriskandarajah et al. 2005). 
More recent data supports this - with the OECD calculating that immigrants pay as much in taxes as they take in benefits (OECD 2013), and that EU workers in the UK take less from the benefits system than native British people do do, as they bring in education paid for by their native countries, and typically return before they require pension support (Dustmann and Frattini 2013).

\section{Productivity}

There is also evidence that immigration can improve competitiveness and productivity. Several studies have highlighted the role of migrants in encouraging new investment, improving efficiency and increasing innovation and entrepreneurship, although there are clear regional and temporal differences (Poot et al. 1988, Poot 2008, Quispe-Agnoli and Zavodny 2002, Saiz 2003). It is argued, for example, that growing social or ethnic diversity due to immigration encourages innovation and entrepreneurship through increasing creativity.

Immigration also increases the size of the local economy, which can potentially lead to more competition and efficiency. In addition, international migration can indirectly affect regional competitiveness through the trade and international linkages that result from a country's diasporas remaining in touch with their country and region of birth. Immigration also has a positive effect on trade between the source country of the immigrants and the host country as immigrants tend to have a preference for the products from their home countries, and furthermore can reduce transaction costs of bilateral trade with their home countries either through individual characteristics such as business contacts or through more generic traits such as language (Poot 2008). Similarly, the potential role of the diasporas in economic development is being increasingly recognised (Cervantes and Guellec 2002, Henoch 2006).

\section{In conclusion}

In conclusion, it is clear that migration is a valid policy approach in the context of the ageing of the UK. There is general consensus that immigration to both the UK and Europe will in the short term achieve immediate increases in total fertility rates, population growth and labour market contribution. The evidence is that migrants contribute to public welfare such as pensions and health care but usually do not draw on them, at least immediately. It was predicted that prior to Brexit, Britain should expect 140,000 net immigrants a year for the next 50 years. In 2013 the Office for Budget Responsibility, calculated that increasing this to 300,000 annually would reduce UK government debt by almost a third - while stopping immigration would increase the debt by almost $50 \%$ (Office for Budget Responsibility 2013).

However, as the 2016 Referendum has also shown, globalisation with its inevitable mass movement of peoples across the globe has significant economic and social impacts on local communities, often not taken seriously by national governments. Migration data is complex, however the national benefit to the economy and society are often clouded by local concerns, including those based on perception rather than experience. 
Ironically, ss a European wide population policy group concluded following the referendum - "the Brexit may push certain EU migrants to apply for citizenship who would otherwise not contemplate applying. This, contrary to the expectation that a Brexit would limit the number of EU migrants in Britain, is likely to increase the number of British citizens possessing a broader set of political and social rights" (People and Policy Compact 2016).

\section{References}

Barrette A, McCarthy Y (2007) Immigrants in a booming economy: analysing their earnings and welfare dependence. Labour, 21, 789-808.

Bonin, H., Raffelhüschen, B., \& Walliser, J. (2000). Can immigration alleviate the demographic burden. Finanz Archiv, 57, 1-21.

Borjas, G. J., \& Hilton, L. (1996). Immigration and the welfare state: immigrant participation in means-tested entitlement programs. Quarterly Journal of Economics, 111, 575-604.

Borjas, G. J., \& Trejo, S. J. (1991). Immigrant Participation in the welfare system. Industrial \& Labor Relations Review, 44, 195-211.

Brücker H, Epstein G, Saint-Paul G, Venturini A, Zimmerman K (2002) Welfare state provision. In: Boeri T, Hanson G, Mccormick B (eds) Immigration policy and the welfare state. Oxford University Press, Oxford.

Cervantes, M., \& Guellec, D. (2002). The brain drain: old myths, new realities. OECD Observer. Paris: OECD.

Coleman DA (2002) Replacement migration, or why everyone is going to have to live in Korea: a fable for our times from the United Nations. Philosophical Transactions of the Royal Society B 357:583-598

CPC (2016) Who are the EU migrants in England and Wales, CPC Briefing 33.

Dustmann, C. and Frattini, T. (2013) Fiscal Effects of Immigration to the UK, Centre for Research and Analysis of Migration Working Paper 2013.

Dustmann, C., Frattini, T., \& Halls, C. (2010). Assessing the fiscal costs and benefits of A8 migration to the UK. Fiscal Studies, 31, 1-41.

Espenshade, T. J. (2001). Replacement migration from the perspective of equilibrium stationary populations. Population and Environment, 22, 383-400.

Espenshade, T. J., Bouvier, L. F., \& Arthur, W. B. (1982). Immigration and the stable population model. Demography, 19, 125-133.

Feld, S. (2000). Active population growth and immigration hypotheses inWestern Europe. European Journal of Population, 16, 3-40.

Fukuyama, F. (1992) The end of history and the last man. The Free Press.

Fukuyama, F. (2014) Political order and political decay. Profile Books.

Gott, C., \& Johnson, K. (2002). The migrant population in the UK: fiscal effects. Development and statistics directorate occasional paper no. 77. London: Home Office.

Hansen, J., \& Lofstrom, M. (2003). Immigrants assimilation and welfare participation. The Journal of Human Resources, 38, 74-98.

Harper, S. (2012). Environment, migration and the European demographic deficit. Environmental Reseach Letters, 7(1).

Harper, S. (2013). Population-environment enteractions: European migration, population composition and climate change. Environmental and Resource, 55(4), 525-541.

Henoch, B. T. (2006). An innovation framework for analysing and facilitating diasporas contribution to poverty reduction in developing countries. World Review of Science, Technology and Sustainable Development, 13, 17-36.

IOM (2010) World migration report 2010.

Leeson, G. (2010). Migrant carers - saving or sinking the sustainability of eldercare? Journal of Population Ageing, 3(1-2), 1-6.

Lesthaeghe R (2000) Europe's demographic issues: fertility, household formation and replacement migration. United Nations Expert Group Meeting on policy responses to population ageing and population decline. New York, United Nations, Population Division. 20-1. 
Lutz, W., and Scherbov, S. (2007) The Contribution of Migration to Europe's Demographic Future: Projections for the EU-25 to 2050. Interim Report IR-07-024. International Institute for Applied Systems Analysis.

Migration Advisory Committee (2012). Analysis of the Impacts of Migration, London: Migration Advisory Committee: https://www.gov.uk/government/uploads/system/uploads/attachment_data/file/257235/ analysis-of-the-impacts.pdf

OECD (2013) International Migration Outlook 2013.

OECD (2016) Recruiting immigrant workers: Europe OECD/EU, 2016

Office for Budget Responsibility (2013) Fiscal Sustainability Report, July 2013.

People and Policy Compact (2016) Brief No 12.

Pollard, J. H. (1973). Mathematical models for the growth of human populations. Cambridge: Cambridge University Press.

Poot, J. (2008). Demographic change and regional competitiveness: the effects of immigration and ageing. International Journal of Foresight Innovation Policy, 4, 129-145.

Poot, J., Nana, G., \& Philpott, B. (1988). International migration and the New Zealand economy: a long-run perspective. Wellington: Institute of Policy Studies.

Prskawetz, A., Mahlberg, B., Skirbekk, V. et al. (2006). The impact of population ageing on innovation and productivity growth in Europe. European Observatory on Demography and the Social Situation, European Commission, Brussels.

Quispe-Agnoli, M., \& Zavodny, M. (2002). The effect of immigration on output mix, capital, and productivity. Federal Reserve Bank Atlanta Economic Review, Q1, 1-11.

Rendall, M. S., \& Ball, D. J. (2004). Immigration, emigration and the ageing of the overseas born population in the United Kingdom. Population Trends, 116, 18-27.

Saczuk, K. (2003) Development and critique of the concept of replacement migration. CEFMR working paper 4/2003. Central European Forum for Migration Research, Warsaw.

Saiz, A. (2003). The impact of immigration on American cities: an introduction to the issues. Business Review, Q4, 14-23.

Sriskandarajah, D., Cooley, L., Reed, H. (2005) Paying their way: the fiscal contribution of immigrants in the UK. 